\title{
Diet and Forage Intake of Cattle on Desert Grassland
}

Range

MARK D. HAKKILA, JERRY L. HOLECHEK, JOE D. WALLACE, DEAN M. ANDERSON, AND MANUEL CARDENAS

\section{Abstract}

Cattle production on desert grassland ranges in southern New Mexico has been low, although limited research shows diet nutritional quality of cattle is adequate to meet production needs during most seasons. Forage intake data are lacking for cattle on desert grassland ranges. Five esophageal-fistulated steers were used to evaluate diet quality and botanical composition on desert grassland range in southern New Mexico. Another 6 steers were used to collect feces to determine intake. Cattle changed their diet with seasonal advance to maximize diet quality. Crude protein concentrations of cattle diets were well above those needed for lactation and daily gain during spring and summer. Diet samples were high in neutral detergent fiber $(66-81 \%)$, sugzesting low energy in the forage. Low forage intake was the main nutritional constraint identified. Even during the summer growing season, organic matter intake never exceeded $1.5 \%$ of body weight. We speculate low intakes may have resulted from high summer temperatures that reduced grazing time. During the late fall and winter, low forage quality appears to explain suppressed intake. Protein supplementation in late fall and winter, and energy supplementation in spring, should be advantageous. We caution that data on diet quality without information on forage intake may poorly describe nutritional status of range cattle.

Key Words: rangelands, ruminants, nutrition, forages

Diets of range cattle in southern New Mexico appear to contain adequate concentrations of crude protein and digestible organic matter during most of the year. However, Herbel et al. (1984) reported that calf production on desert grassland ranges was low (142 kg/cow/year). This could be the result of inadequate forage intake. The object of our study was to quantify quality of cattle diets and forage intake on southern New Mexico desert grassland range in good condition.

\section{Study Area and Methods}

This study was conducted on the Jornada Experimental Range in Dona Ana County, southcentral New Mexico. Elevation of the study pasture ranges from 1,310 to $1,330 \mathrm{~m}$. Long-term precipitation averages $22.8 \mathrm{~cm}$. Precipitation during the study in 1984 was $224 \%$ of the annual average, the highest since recording began in 1914. Study pasture soils are sandy loams. Vegetation is dominated by honey mesquite (Prosopis glandulosa), broom snakeweed (Gutierrezia sarothrae), and mesa dropseed (Sporobolus flexuosus) (Table 1). Swale sites are dominated by vine mesquite (Panicum obstusum). This type of site is common in southern New Mexico and southeastern Arizona.

Water was provided throughout the study period at the southeastern corner of the pasture, and was also available in several swale sites scattered through the pasture. Range condition and forage availability were good near watering points. Consequently, we surmise that travel distance to water had little or no influence on cattle diet quality or forage intake. The reader is referred to Hakkila (1986) for a more detailed description of the study pasture.

The study past ure was stocked at a moderate rate $(30-35 \%$ use of

\footnotetext{
Authors are graduate research assistant, professors, and adjunct professor Department of Animal and Range Sciences, and professor, Department of Experimental Statistics, New Mexico State University, Las Cruces, New Mexico 88003.

Manuscript accepted 11 March 1987.
}

palatable perennial forage species) in February 1984 with 11 experimental cattle (Hereford $X$ Brangus steers). These animais were gentle and trained during the previous fall and winter. Five of the steers were equipped with esophageal fistulae; the other 6 were intact and trained to carry fecal bags. All animals were trained to be easily caught in the pasture by the senior author.

Fecal collections were made in March, May, July, August, October, and December of 1984 for a total of 6. Fecal collection steers were weighed without shrink 14 days before each collection period. All steers were given a 14-day period of acclimation to the pasture. All esophageal fistula collections took place between 0600 and $0900 \mathrm{hr}$ during 3 consecutive days. The steers were not penned before collections and were allowed to graze freely for the duration of each collection period.

All esophageal samples were placed in a forced-air oven at $50^{\circ} \mathrm{C}$ within $2 \mathrm{hr}$ after collection. Dried samples were ground to $1 \mathrm{~mm}$ in a Wiley mill, mixed and composited by animal across days using equal weights of daily samples. Vegetation availability for each esophageal collection was determined by step-point sampling. The procedure involved delineating the area grazed during each esophageal fistula collection and conducting four 100-point step-point transects per day for a total of 1,200 data points per collection period. Concurrently with fistula collections, total fecal output was collected from the 6 intact steers with fecal bags for 4 continuous days.

Botanical composition of cattle diets was determined by the microhistological technique. Sample preparation procedures followed Holechek (1982) while training and diet calculation procedures followed Holechek and Gross (1982a, b). After preliminary training, 10 unknown test diets containing the primary forage species on the study pasture were evaluated with an overall accuracy of $90 \%$ (Hakkila 1986). Five slides evaluated at $100 \mathrm{X}$ were used for all test and study samples.

Dry matter and ash content of all diet and fecal samples were determined by AOAC (1984) methods. Nitrogen content of diet samples was determined by the Kjeldahl method (AOAC 1984). Acid detergent fiber (ADF), acid detergent lignin (ADL), and neutral detergent fiber (NDF) were determined by Goering and Van Soest (1970) procedures. Organic matter in vitro digestibility was determined by Tilley and Terry (1963) procedures as modified by Moore (1970) and Harris (1970). Inoculum was obtained from 2 penned steers fed an alfalfa (Medicago sativa) hay diet. Digestion times of $4,24,36,48,60,72$, and $84 \mathrm{hr}$ were used for all samples. Organic matter intake was calculated by the standard equation of Van Dyne (1969):

Organic matter intake $=-(100) \times$ (total fecal organic matter output $)$ 100 - \% IVOMD (48 hr)

Holechek et al. (1986) found improved in vitro estimates of in vivo digestibility by selecting the maximum in vitro digestibility value for times ranging from 36 to $96 \mathrm{hr}$. We also calculated forage intake using this approach:

Organic matter intake $=\frac{(100) \times(\text { total fecal organic matter output })}{(00)}$ 100 - \% IVOMD (maximum in vitro digestibility)

Intake was expressed as a percentage of body weight (BW) (Cordova et al. 1978). 
Table 1. Botanical composition percentages of steer diet samples and forage availability (\% composition) based on step point transects for 6 collections on desert grasshand range in southeastern New Mexico.

\begin{tabular}{|c|c|c|c|c|c|c|c|c|c|c|c|c|c|c|}
\hline \multirow[b]{2}{*}{ Plant species } & \multicolumn{2}{|c|}{ March } & \multicolumn{2}{|c|}{ May } & \multicolumn{2}{|c|}{ July } & \multicolumn{2}{|c|}{ August } & \multicolumn{2}{|c|}{ October } & \multicolumn{2}{|c|}{ December } & \multirow{2}{*}{$\begin{array}{c}\bar{X} \\
\text { \% Diet } \\
\end{array}$} & \multirow{2}{*}{$\begin{array}{c}\bar{X} \\
0 \text { Comp } \\
\end{array}$} \\
\hline & \% Diet & $\%$ Comp & \% Diet & \% Comp & \% Diet & $\%$ Comp & \% Diet & $\%$ Comp & $\%$ Diet & $\%$ Comp & $\%$ Diet & $\%$ Comp & & \\
\hline Aristida longiseta & 1 & $\mathrm{t}$ & 9 & 1 & 3 & $t$ & 1 & 1 & 1 & 3 & 2 & 1 & 2 & 1 \\
\hline Bouteloua eriopoda & 8 & $\mathrm{t}$ & - & - & - & - & $\mathrm{t}$ & 1 & 2 & 1 & - & $\mathrm{t}$ & 2 & $\mathrm{t}$ \\
\hline Erioneuron pulchellum & - & 10 & 16 & 20 & - & 2 & - & 8 & - & 5 & - & 10 & 1 & 10 \\
\hline Muhlenbergia porteri & - & 1 & 1 & - & - & $\mathbf{t}$ & 3 & $\mathrm{t}$ & $\mathbf{t}$ & 1 & $\mathrm{t}$ & $t$ & $\mathrm{t}$ & $\mathrm{t}$ \\
\hline Panicum obtusum & - & $\mathrm{t}$ & - & - & 56 & 32 & - & - & 33 & 14 & - & 7 & 13 & 7 \\
\hline Sporobolus airoides & - & - & - & - & 2 & 1 & - & - & - & 1 & - & $\mathrm{t}$ & $\mathrm{t}$ & $\mathrm{t}$ \\
\hline Sporobolus flexuosus & 25 & 20 & 46 & 62 & 9 & 8 & 75 & 27 & 5 & 22 & 71 & 28 & 36 & 28 \\
\hline Total Grasses & 34 & 32 & 73 & 83 & 70 & 44 & 78 & 38 & 40 & 48 & 73 & 50 & 61 & 48 \\
\hline Amaranthus retroflexus & - & - & $t$ & - & $t$ & 5 & - & - & - & - & - & $\mathbf{t}$ & $\mathrm{t}$ & $\mathrm{t}$ \\
\hline Ambrosia confertifolia & - & - & $\mathrm{t}$ & $t$ & 5 & $\mathrm{t}$ & 1 & 3 & $\mathrm{t}$ & I & - & $\mathrm{t}$ & 1 & $i$ \\
\hline Baileya multiradiata & 1 & 6 & $\mathrm{t}$ & 3 & $\mathrm{t}$ & i & 1 & 3 & 1 & 1 & - & 3 & $\mathrm{t}$ & 3 \\
\hline Cassia bauhinoides & - & - & 2 & 2 & 7 & 2 & 4 & 3 & 1 & 1 & 1 & $\mathrm{t}$ & 2 & 1 \\
\hline Croton corymbulosus & - & 3 & - & - & 6 & 12 & 6 & 12 & 21 & 9 & 2 & $\mathbf{3}$ & 7 & 6 \\
\hline Descurainia pinnata & 31 & 16 & - & - & - & - & - & - & - & - & - & - & 8 & 4 \\
\hline Dithyrea wislizeni & - & - & 8 & 3 & 1 & 4 & 1 & 4 & 1 & 1 & 1 & - & 1 & $i$ \\
\hline Linum vernale & - & - & - & $\mathrm{t}$ & 1 & 2 & - & 1 & - & - & - & $t$ & $\mathrm{t}$ & $i$ \\
\hline Nama hispidum & - & - & 9 & 5 & - & $\mathrm{t}$ & - & $\mathrm{t}$ & - & - & - & - & i & 1 \\
\hline Salsola kali & - & - & - & - & 5 & $\mathrm{t}$ & $\mathbf{t}$ & $\mathrm{t}$ & $\mathfrak{t}$ & 1 & - & - & $\mathrm{t}$ & $\mathrm{t}$ \\
\hline Solanum eleaegnifolium & - & - & 2 & $\mathbf{t}$ & $\mathrm{t}$ & 2 & - & 1 & $\mathrm{t}$ & $t$ & - & $\mathbf{t}$ & $\mathrm{t}$ & $t$ \\
\hline Sphaeralcea spp. & - & $t$ & 4 & $\mathrm{t}$ & $i$ & 1 & - & 1 & - & 1 & - & - & $\mathrm{t}$ & $\mathrm{t}$ \\
\hline Tidestromia lanuginosa & - & - & - & - & - & $\mathrm{t}$ & $\mathbf{t}$ & $i$ & - & $\mathrm{t}$ & - & - & $\mathrm{t}$ & $\mathrm{t}$ \\
\hline Tribulus terrestris & - & - & - & - & 3 & 3 & - & $\mathrm{t}$ & - & - & - & - & $\mathrm{t}$ & $\mathrm{t}$ \\
\hline Total Forbs & 32 & 25 & 26 & 14 & 32 & 32 & 13 & 35 & 25 & 19 & 3 & 10 & 22 & 19 \\
\hline Atriplex canescens & 8 & 1 & 1 & - & 1 & $\mathrm{t}$ & 1 & $\mathbf{t}$ & 2 & 2 & 2 & $\mathbf{t}$ & 3 & 1 \\
\hline Gutierrezia sarothrae & 4 & 31 & - & 2 & - & 20 & - & 20 & 4 & 24 & 6 & 26 & 3 & 24 \\
\hline Prosopis glandulosa & 10 & 9 & - & i & 1 & 4 & 8 & 7 & 29 & 5 & $\mathrm{t}$ & 9 & 11 & 7 \\
\hline Yucca elata & 14 & 2 & 1 & $\mathrm{t}$ & $\mathrm{t}$ & $i$ & 1 & $i$ & 1 & $\mathrm{t}$ & 17 & 2 & 8 & 1 \\
\hline Total Shrubs & 35 & 43 & 2 & 4 & 2 & 26 & 10 & 28 & 36 & 32 & 23 & 38 & 18 & 33 \\
\hline
\end{tabular}

$t=$ trace

\section{Results and Discussion}

\section{Botanical Diet Composition}

Mesa dropseed was the most important species in cattle diet when samples were pooled across all seasonal collections (Table 1). Other important species in the diet included vine mesquite, leatherweed croton (Croton corymbulosus), tansy mustard (Decurainia pinnata), honey mesquite, and soaptree yucca (Yucca elata). Grasses comprised more than $70 \%$ of the cattle diet during the summer (May, July, August collections) and winter (December collection). Forbs and shrubs collectively comprised more than $60 \%$ of the diet in the spring (March collection) and fall (October collection).

Our data are largely consistent with Rosiere et al. (1975a) for both key species and dietary trends for cattle on sandy loam rangelands in southcentral New Mexico. However, they reported no consumption of vine mesquite while we observe it to be the second most important plant in the diet. This exception appears to be due to difference among study sites.
Honey mesquite was the most abundant shrub in cattle diets, accounting for $11 \%$ of the overall diet. Nearly all the honey mesquite consumed in August and October was fruits. In March, honey mesquite consumption involved primarily dead leaves dropped in 1983 that were grubbed from the sand dunes along with young tansy mustard plants. Rosiere et al. (1975a) attributed toxicity problems in cows to heavy spring consumption of tansy mustard. However, in our study, none of the steers showed toxicity symptoms.

Our study substantiates the findings of Herbel and Nelson (1966) and Rosiere et al. (1975a) that show the dominance of grass and importance seasonal of forbs and shrubs in cattle diets on desert grassland ranges in the southwestern United States. Herbel and Nelson (1966), Rosiere et al. (1975a), and our study all show cattle select for succulent vegetation. Major seasonal shifts in diet occur in response to changes in plant phenology and availability. Grasses are heavily used in the summer when actively growing, but cattle readily switch to forbs and shrubs if they are available after the grasses mature.

Table 2. Diet chemical composition (organic matter basis), digestibility and forage intake for steers graxing grassland range in southeastern New Mexico.

\begin{tabular}{|c|c|c|c|c|c|c|c|c|c|c|c|c|}
\hline & \multicolumn{2}{|c|}{ March } & \multicolumn{2}{|c|}{ May } & \multicolumn{2}{|c|}{ July } & \multicolumn{2}{|c|}{ August } & \multicolumn{2}{|c|}{ October } & \multicolumn{2}{|c|}{ December } \\
\hline & $\bar{x}$ & SE & $\overline{\boldsymbol{x}}$ & SE & $\bar{x}$ & SE & $\bar{x}$ & SE & $\bar{x}$ & SE & $\bar{x}$ & $\mathbf{S E}$ \\
\hline Neutral detergent fiber $\%$ & 71.2 & 3.8 & 90.2 & 1.4 & 75.2 & 1.3 & 75.0 & .8 & 66.4 & 1.6 & 80.8 & 1.0 \\
\hline Acid detergent fiber $\%$ & 63.1 & 7.3 & 66.2 & 1.4 & 52.3 & 1.0 & 48.1 & .4 & 51.9 & .5 & 59.6 & .5 \\
\hline Acid detergent lignin \% & 10.7 & .4 & 8.4 & 1.1 & 9.3 & 1.0 & 5.9 & .4 & 10.7 & 1.2 & 9.7 & .4 \\
\hline $48 \mathrm{hr}$ IVOMD\%1 & 47.9 & 1.1 & 55.4 & 1.2 & 50.2 & 1.0 & 62.7 & 1.2 & 47.5 & 1.6 & 41.1 & .9 \\
\hline Max IVOMD\% & 60.4 & 1.1 & 70.1 & 1.4 & 66.7 & 1.8 & 66.2 & .8 & 52.0 & 2.4 & 50.7 & 1.2 \\
\hline Crude protein \% & 15.6 & 1.6 & 13.5 & .3 & 13.9 & .3 & 14.0 & .2 & 12.7 & .5 & 7.2 & .4 \\
\hline OMI (48 hr IVOMD) $)^{2}$ & .9 & .1 & 1.4 & .1 & 1.3 & .1 & 1.5 & .1 & 1.4 & .1 & 1.3 & $<.1$ \\
\hline OMI $\left(\max\right.$ IVOMD $^{3}$ & 1.2 & .1 & 2.2 & .1 & 1.9 & .1 & 1.7 & .1 & 1.5 & .1 & 1.6 & $<1$ \\
\hline
\end{tabular}

IVOMD = in vitro organic matter digestibility

${ }^{2} \mathrm{OMI}=$ organic matter intake (\% body weight) using $48 \mathrm{hr}$ IVOMD.

${ }^{3} \mathrm{OMI}=$ organic matter intake (\% body weight) using the maximum ivOMD selected from 36, 48, 60, 72, 84 and $96 \mathrm{hr}$ times. 


\section{Diet Quality}

Crude protein levels never dropped below $7 \%$ (organic matter basis) in our study (Table 2). Rosiere et al. (1975b), on similar range in southcentral New Mexico, reported the lowest crude protein level in fall (7.3\%) whereas, in our study, it occurred in winter $(7.2 \%)$. This is explained by differences in annual precipitation distribution in the $\mathbf{2}$ studies. Iate summer and fall precipitation was much higher in our study, which delayed forage maturity.

Crude protein concentrations are considered adequate for growing heifers and steers (minimum wt $225 \mathrm{~kg}$ ) gaining $0.5 \mathrm{~kg}$ per day (9.5-10\%, organic matter basis), yearling heifers (8-9\%, organic matter basis), lactating cows (9-10\%, organic matter basis), and heifers (9-11\%, organic matter basis) in all periods except December, based on NRC (1984) requirements. Crude protein concentrations needed by pregnant, nonlactating cows $(7-8 \%$, organic matter basis) were met in all periods. These requirements by NRC (1984) are made on the basis of ration feeding with limited intake and as a result may be too high for range forage.

McCollum et al. (1985) found $\mathrm{N}$ availability decreased as total diet $\mathbf{N}$ decreased for cattle on shortgrass range in New Mexico. His data indicate total $\mathbf{N}$ may be misleading about protein adequacy for cattle consuming low-quality diets.

In vitro digestibility values for organic matter showed large fluctuations between collection periods (Table 2). This was true for both maximum and 48-hr in vitro digestion values. These 2 measures of in vivo digestibility were not highly correlated $(r=.77, n=$ 6). Other studies (Milchunas et al. 1978; Holechek and Vavra 1982, 1983; Holechek et al. 1986) show digestibility coefficients for organic matter can be misleading about forage energy value because forages with the highest digestion coefficients do not always have the highest intakes. Based on our analysis of the literature and results from this study, it appears that major reductions in forage intake by cattle occur when $48-\mathrm{hr}$ in vitro organic matter digestibility (IVOMD) values drop below $50 \%$ and maximum IVOMD (in vivo digestibility) values drop below $65 \%$. Beyond this observation, differences in digestibility values are generally uninterpretable.

Neutral detergent fiber (NDF) levels were high $\bar{x}=76 \%$ ) compared to other range studies evaluating this cattle diet nutritional characteristic. Holechek and Vavra (1983) reported an average diet NDF level of $71 \%$ for cattle on mountain range in Oregon. On shortgrass range in New Mexico, cattle diets had an average NDF level of $71 \%$ (McCollum et al. 1985). The negative relationship between diet NDF level and forage intake of ruminants is well established (Van Soest 1982). It is important to recognize that our data were collected in a year of above-average forage availability and a longer than average period of active forage growth. During more normal conditions, even higher dietary NDF levels would be expected. The high NDF levels of cattle diets in our study suggest that low energy intake may be an important constraint on cattle productivity on desert grassland ranges.

\section{Fornge Intake}

Forage intake values averaged across collections (Table 2) were $1.3 \%$ and $1.7 \% \mathrm{BW}$, respectively, for $48-\mathrm{hr}$ and maximum IVOMD procedures. These data are much below cattle forage intake determinations on other ranges reviewed by Van Dyne et al. (1980) who showed cattle consume between $1.8-2.0 \% \mathrm{BW}$ on an organic matter basis when grazing season or yearly estimates are averaged. Most of the studies used 48-hr IVOMD to estimate forage intake from fecal output. Thus, it appears intake is reduced about $35 \%$ on desert grassland ranges compared to other types.

Total grazing time by cattle frequently decreases during hot weather (Seath and Miller 1946, 1947; Ehrenreich and Bjugstad 1966; Dwyer 1961). Daytime temperatures were typically above $32^{\circ} \mathrm{C}$ between mid-May and late-September, and nighttime temperatures were above $18^{\circ} \mathrm{C}$. Seath and Miller $(1946,1947)$ in Louisiana found cattle grazing time decreased when daytime temperatures exceeded $26^{\circ} \mathrm{C}$. Shade was generally unavailable in our study pasture. Sheep in Australia grazed $10.4 \mathrm{hr}$ during summer when provided with shade, compared to $9.0 \mathrm{hr}$ when shade was unavailble (Arnold and Dudzinski 1978).

In March, when temperatures were still fairly cool, lack of actively growing forage was probably the main reason for low forage intake. Cattle frequently ate tansy mustard, a cool-season forb that was actively growing. Previous year's growth on mesa dropseed plants, although available, was generally rejected in favor of the tansy mustard.

We attribute the reduced intake value in December to low diet quality. Perennial grasses, particularly mesa dropseed, were available. However, they had matured with the onset of overnight freezing temperatures in November. Cool-season forbs were in the rosette growth form and thus their quantity was low. The low organic matter digestibility and crude protein values, in conjunction with a high NDF concentration, suggest low diet quality was the main factor suppressing forage intake.

\section{Management Implications}

Springs in southern New Mexico are generally dry and few perennial grasses grow. However, in most years cattle diet quality is high in spring because of forbs growing after winter precipitation. Energy supplements in this period should be more advantageous than protein supplements. Grain or medium quality hays (8-10\% crude protein) may be particularly advantageous to lactating cows. During summer, manipulation of animal comfort factors might improve performance by increasing forage intake. These manipulations include provisions of shade and minimizing travel distance to water. In fall and winter, protein concentrations in cattle diets appear borderline in terms of meeting maintenance needs. If grazing pressure is moderate, forage quantity should be adequate. Between mid-October and late-February, limited protein supplementation, such as providing $0.50 \mathrm{~kg}$ of cottonseed cake per cow per day, may improve forage intake by better meeting $\mathbf{N}$ requirements of rumen microbial populations. Winter weight losses of cattle have been reduced by protein supplementation in southern New Mexico (Lantow 1930).

\section{Literature Cited}

AOAC. 1984. Official methods of analysis (13th ed.). Association of Official Analytical Chemists. Washington, D.C.

Arnold, G.W., and M.L. Dudzinski. 1978. Ethology of free-ranging domestic animals. Elsevier Scientific Pub. Co., New York.

Cordova, F.J., J.D. Wallace, and R.D. Pieper. 1978. Forage intake by grazing livestock: A review. J. Range Manage. 31:430-438.

Dwyer, D.D. 1961. Activities and grazing preferences of cows with calves in Northern Osage County, Oklahoma. Oklahoma Agr. Exp. Sta. Bull. B-588.

Ehrenreich, J.H., and A.J. Bjugatad. 1966. Cattle grazing time is related to temperature and humidity. J. Range Manage. 19:141-142.

Goering, H.K., and P.J. Van Soest. 1970. Forage fiber analysis (apparatus, reagents, procedures and some applications). USDA-ARS Handbook No. 379.

Hakkila, M.D. 1986. Beef steer diets, forage intake, and fecal indices in southcentral New Mexico. M.S. Thesis. New Mexico State Univ., Las Cruces.

Harris, L.E. 1970. Nutrition research techniques for domestic and wild animals. Vol. 1. L.E. Harris, Utah State Univ, Logan.

Herbel, C.H., and A.B. Nelson. 1966. Species preferences of Hereford and Santa Gertrudis cattle on a southern New Mexico range. J. Range Manage. 19:177-181.

Herbel, C.H., J.D. Wallace, M.D. Finkner, and C.C. Yarbrough. 1984. Early weaning and part-year confinement of cattle on arid rangelands of the southwest. J. Range Manage. 37:127-130.

Holechek, J.L. 1982. Sample preparation techniques for microhistological analysis. J. Wildl. Manage. 46:502-505.

Holechek, J.L., and B.D. Gross. 1982a. Training needed for quantifying simulated diets from fragmented range plants. J. Range Manage. 35:644-647.

Holechek, J.L., and B.D. Gross. 1982b. Evaluation of diet calculation procedures for microhistological a nalysis. J. Range Manage. 35:743-745. 
Holechek, J.L., and M. Vavra. 1982. Forage intake by cattle on forest and grassland ranges. J. Range Manage. 35:640-645.

Holechek, J.L., and M. Vavra. 1983. Drought effects on diet and weight gains of yearling heifers in northeastern Oregon. J. Range Manage. 36:227-231

Holechek, J.L., H. Wofford, D. Arthun, M.L. Galyean, and J.D. Wallace.1986. Evaluation of total fecal collection for measuring cattle forage intake. J. Range Manage. 39:2-4.

Lantow, J.L. 1930. Supplemental feeding of range cattle. New Mexico State College Agr. Exp. Sta. Bull. 185. Las Cruces.

McCollum, F.T., M.L. Galyean, K.J. Krysl, and J.D. Wallace. 1985. Cattle grazing blue grama rangeland $I$. Seasonal diets and rumen fermentation. J. Range Manage. 38:539-543.

Milchunas, D.G., M.I. Dyer, O.C. Wallmo, and D.E. Johnson. 1978. In vivo-in vitro relationships of Colorado mule deer forages. Colorado Div. Wildlife Spec. Rep. 43. Fort Collins.

Moore, J.E. 1970. Procedures for the two-stage in vitro digestion of forages. In: Nutrition research techniques for domestic and wild animals Vol. p. 5501. L.E. Harris, Utah State Univ., Logan.

NRC. 1984. Nutrient requirements of domestic animals. No. 4. Nutrient requirements of beef cattle (6th ed.). Nat. Acad. Sci. Nat. Res. Council. Washington, D.C.
Rosiere, R.E., R.F. Beck, and J. Wallace. 1975a. Cattle diets on semidesrt grassland: botanical composition. J. Range Manage. 28:89-93.

Rosiere, R.E., J.D. Wallace, and R.F. Beck. 1975b. Cattle diets on semidesert grassland: nutritive content. J. Range Manage. 28:94-96.

Seath, D.M., and G.D. Miller. 1946. Effect of warm weather on grazing performance of milking cows. J. Dairy Sci. 29:921-925.

Seath, D.M., and G.D. Miller. 1947. Effect of hay feeding in summer on milk production and grazing performance of dairy cows. J. Dairy Sci. 39:921-925.

Tilley, J.M.A., and R.A. Terry. 1963. A two-stage technique for the in vitro digestion of forage crops. J. Brit. Grassl. Soc. 18:104-111.

Van Dyne, G.M. 1969. Measuring quantity and quality of the diet of large herbivores. In: F.G. Golley and H.K. Buechner, eds. A Practical Guide to the Study of the productivity of large herbivores. Blackwell Sci. Publ., Oxford, England.

Van Dyne, G.M., N.R. Brockington, Z. Szocs, J. Duek, and C.A. Ribic. 1980. Large herbivore subsystem. In: A.I. Breymeyer and G.M. Van Dyne. (Eds.). Grasslands systems analysis and man. Cambridge Univ. Press, Cambridge, England.

Van Soest, P.J. 1982. Nutritional ecology of the ruminant, O \& B Books Inc., Corvallis, Ore. 